\title{
Coleoptera assemblages of pine forests depends on the distance to the source of nitrogen pollution
}

\author{
V. Tamutis ${ }^{1,2}$ and J. Skłodowski ${ }^{3,4}$ \\ ${ }^{1}$ Institute of Biology and Plant Biotechnology, Aleksandras Stulginskis University, Studentu 11, Akademija, Kaunas \\ distr.,LT-53361,Lithuania.E-mail:vytautas.tamutis@asu.lt \\ ${ }^{2}$ Kaunas T. Ivanauskas Zoological Museum, Laisvès al. 106, LT-44253 Kaunas, Lithuania. \\ E-mail: entomol@zoomuziejus.lt \\ ${ }^{3}$ Department of Forest Protection and Ecology; Warsaw University of Life Sciences; Nowoursynowska 159; 02-776 \\ Warszawa, Poland.E-mail: jaroslaw.sklodowski@wl.sggw.pl \\ ${ }_{4}^{4}$ Corresponding author. Tel.: +48225938 164; fax: +48225938 154.E-mail: jaroslaw.sklodowski@wl.sggw.pl
}

Keywords: Ammonia, Carbon content, Eutrophication, Indicator species, IndVal, Nitrogen emission, Reduction of emission.

\begin{abstract}
The paper analyzed the changes of beetle assemblages in the litter layer of eutrophic pine forests in the zone polluted by a nitrogen fertilizer plant Joint Stock Company "Achema" (Lithuania). We hypothesized that abundance, diversity and life traits of beetle assemblages depend on the distance from the pollution source. The samples of the litter layer were taken from pine stands at the distances of 3,5,10 and $20 \mathrm{~km}$ from the plant. The PCA and GLM analyses were used to reduce the number of variables to the main environmental gradient and assess the influence of environmental factors on beetle abundance, number of species, and life traits. The dependence of species number, abundance and the presence of forest and dendrophagous species on the distance from the plant was detected. A significant impact of organic carbon content, nitrogen emission and moss cover on other life traits of beetles was disclosed. The abundance of moss fraction in the litter layer was positively correlated with increasing distance from the plant. The ability to tolerate polluted sites by three species: Atheta fungi, Micrambe abietis and Brassicogethes aeneus, and intolerance of pollution by eight species: Bryaxis puncticollis, Quedius limbatus, Cyphon pubescens, Cephenium majus, Cyphon padi, Cyphon variabilis, Gabrius appendiculatus and Philonthus cognatus, were detected by IndVal analysis. The distribution of litter species was affected by the distance from the plant and by the richness of moss cover.
\end{abstract}

\section{Introduction}

Changes in forest ecosystems are related to the impacts of natural and anthropogenic factors (Chappelka and FreerSmith 1995, Manion and Lachance 1992, Augustaitis et al. 2005). Since the last decades of the $20^{\text {th }}$ century, there have been considerable changes in forests across Europe caused by air pollution, especially by ground-level ozone $\left(\mathrm{O}_{3}\right)$, sulphur (S) and nitrogen $(\mathrm{N})$ oxides (Heliövaara and Väisänen 1988, Emberson et al. 2007, Paatero et al. 2008, Rizvi et al. 2012). Humans are altering the global cycle of nitrogen via combustion of fossil fuels, production of nitrogen fertilizers, cultivation of nitrogen-fixing legumes, and other actions (Galloway et al. 1995). It has been estimated that more than $60 \%$ of nitrogen oxides in the atmosphere are derived from human activity (Logan 1983) and are widely considered anthropogenic nitrogen (Boyer et al, 2002). The deposition of anthropogenic nitrogen from the atmosphere strongly affects terrestrial ecosystem processes.

The deposition of anthropogenic nitrogen from the atmosphere strongly affects terrestrial ecosystem processes. Crowns of trees are an excellent location for dust deposition, which enriches forest ecosystems with an additional portion of elements, as well as nitrogen compounds. The amount of dust deposition depends on the tree species (Simon 2016a).
Nitrogen deposition may increase primary production (Aber et al. 1989), favour nitrophilic plant species in vegetation communities (Marozas et al. 2008,) as well as modify interactions between plants and insects (Mattson 1980). Pollution poses a considerable threat to forest ecosystems, but on the other hand different organisms have varying sensitivities to different pollutants. For instance, lichens and some species of mites differ in their sensitivity to sulphur dioxide (Thormann 2006), vascular plants differ in their sensitivity to ozone (Felzer et al. 2007), and herbs, shrubs and herbivorous insects differ in their sensitivity to nitrogen (Marozas et al. 2008, Throop and Lerdau 2004). This variation in sensitivity suggests that air-pollution stress affects the biodiversity of ecosystems, either in shifting species composition or the outright loss of sensitive species (Lukac and Godbold 2011). The arthropods are the most numerous group of animals in forests ecosystems (Perry 1994), and they perfectly reflect the impact of various factors on forest ecosystems by changes in their species composition and assemblage structure (Führer 1985, Heliövaara and Väisänen 1988, Xu et al. 2009). The cessation of pollution (e.g., phosphate) stimulates the increasing of plant diversity and therewith the increasing of diversity and abundance of different functional groups of herbivores (chewers, miners, cell-tissue suckers and vascular suckers). While among carnivores and detritivores, only the sucking 
hunters have been found to produce a significant positive correlation with plant species richness (Perner et al. 2003). Studies on acidification and nitrogen fertilization of plots established in a young Scotch pine plantation have shown that dry deposition of sulphur and wet deposition of sulphuric acid hamper the increace of late successional carabid fauna in assemblages (forest species, zoophagous species, autumn breeders), but small dosages of nitrogen fertilization accelerate those (Skłodowski 1995).

A higher level of nitrogen deposition in the soil and a higher concentration of nitrogen in the air still are found near Joint Stock Company "Achema", a nitrogen fertilizer plant, which is the largest nitrogen fertilizer producer in the Baltic countries. A lot of chemicals, such as ammonia, methanol, carbamate, formalin and their products have been produced since 1965 in this plant (Anonymous 2015). The first reports of damage to the forest ecosystems close to the plant were described in 1972 (Armolaitis et al. 1999). A large-scale death of trees and the diminishing of shrub and moss cover in an area of 4000 ha of the surrounding forest were a consequence of enhanced production at the plant in the period 1979-1988 (Armolaitis et al. 1999). The process of ecosystem collapse was stopped when emission of pollutants was reduced from 40,000 tons per year in 1981 to 11,000 tons in 1990 (Armolaitis et al. 2013). The ongoing regeneration of forest ecosystems has been observed since 1999 as a consequence of reducing the emission of pollutants to 2,400 tons per year in 2013 (Anonymous 2015). In 2012, air pollution by ammonia $\left(\mathrm{NH}_{3}\right)$ and nitrogen-oxid $(\mathrm{NO})$ was higher than typical Lithuanian background levels only within a range of 6 $\mathrm{km}$ from the plant (Armolaitis et al. 2013). The concentration of sulphur (S) in the air has fell to the general limits, even in the stands situated less than $2 \mathrm{~km}$ from the plant (Armolaitis et al. 2013).

Research has been focused on the process of regeneration of forest ecosystems around the nitrogen fertilizer plant, as well as analysis of the state of different habitat structures: conditions of the crowns of trees and defoliation (Armolaitis and Stakenas 2001, Augustaitis 2005), state of stems and their radial growth (Stravinskienè 2004), epiphytical microflora and needles (Kupčinskienè et al. 2000), cover of shrubs, herbs and bryophytes (Armolaitis and Stakènas 2001, Marozas et al. 2008) as well as the chemical composition of the soil (Armolaitis and Stakenas 2001).

Long-term accumulation of nitrogen and sulphur in the soil in pine forests surrounding Achema has led to the loss of some plant species typical of such pine forest, e.g., Vaccinium myrtillus, Vaccinium vitis-idea, and increase in the frequencies of nitrophilic plants, including Galeopsis tetrahit, Stellaria graminea, Rubus idaeus, Chamerion angustifolium etc. (Marozas et al. 2008). Deposition of acidifying compounds has been shown to have the most significant effect on pine tree defoliation as well as on the diversity of soil microarthropods and diversity of stream macroinvertebrates (Augustaitis et al. 2005). However, no significant impacts on the level of defoliation of trees and acidification of the soil have been observed since the reduction of the plant's emis- sions. Moreover, a higher activity of the process of humification, which increased the concentration of organic carbon $(\mathrm{C})$ at the distance of up to $6 \mathrm{~km}$ from the plant, was observed in the forest litter and upper horizons of soil during that period (Armolaitis et al. 2013).

The long-term nitrogen loading on grasslands was observed to have a negative effect on the species richness of herbivores and predator insects, while the total insect abundance and species richness of detritivores increased (Hadad et al. 2000). Studies on the effects of $\mathrm{N}$ deposition on the ecosystem and on herbivores were also carried out by Throop and Lerdau (2004); however, its effect on insects inhabiting forest litter layers remains poorly investigated. Nitrogen deposition impacts the litter layer and soil humus and as a consequence might change species composition and structure of arthropod assemblages inhabiting this layer of the ecosystem.

Within a short distance (up to $6 \mathrm{~km}$ ) from the plant, the forest is affected by a high concentration of pollutants in the air (even several years after reduction of the plant's emission of pollutants) (Armolaitis et al. 2013), which per force are accumulated in forest litter; therefore, we suppose that those could have a crucial impact on arthropod assemblages in the area. We expect that different diet specialists (e.g., phytophagous, saprophagous, zoophagous etc.) and different habitat specialists (e.g., forest, open area and generalists) could react differently to the changes in the forest ecosystem under a different impact of pollution from the plant.

We considered the following exploratory questions: (1) Is the number of species and individuals in the beetle assemblages situated closer to the nitrogen fertilizer plant lower compared with assemblages at sites further away? (2) Are the proportions of diet and habitat specialists in beetle assemblages related to the distance from the plant? (3) Is it possible to distinguish litter coleopteran species which can be used as indicators of polluted forest ecosystems?

\section{Material and methods}

\subsection{Site characteristics}

The studies were conducted in eight plots, established in 65-100 year-old Scots pine (Pinus sylvestris L.) stands (type: Pinetum vaccinio-mirtyllosum) situated in the central part of Lithuania from October to April 2013-2014. The plots were located along a $21 \mathrm{~km}$ long transect northeast of the plant (downwind according to the prevailing winds in the region) (Fig. 1). The research plots were located at four different distances from the plant: 2-3 km (plots A1-A2), 5-6 $\mathrm{km}$ (plots B1-B2), 10-11 km (plots C1-C2) and 19.8-20.5 $\mathrm{km}$ (plots D1-D2), which were considered as distinct distance classes: 3, 5, 10 and $20 \mathrm{~km}$, respectively, in further data analyses (Tables 1 and 2). Soil humidity in each research plot was mesic (no inundation during spring after snow melting). Geobotanical characteristics were recorded according to the Braun-Blanquet scale. Stand age and leaf area index data were taken from the forest inventory. 
Table 1. Species composition of studied stands (two tree layers and shrub layer) and litter samples: explanation of species presence: + - solitary individuals, 1 - individuals covering less than $20 \%$ of area, 2 - individuals covering $20-25 \%$ of area, 3 - individuals covering $25-50 \%$ of area, 4 - individuals covering $50-75 \%$ of area, 5 - individuals covering more than $75 \%$ of area.

\begin{tabular}{|c|c|c|c|c|c|c|c|c|}
\hline \multirow{2}{*}{$\begin{array}{l}\text { Plot } \\
\text { Replicates }\end{array}$} & \multicolumn{2}{|c|}{$\mathrm{A}$} & \multicolumn{2}{|l|}{$\mathrm{B}$} & \multicolumn{2}{|l|}{$\mathrm{C}$} & \multicolumn{2}{|l|}{$\mathrm{D}$} \\
\hline & $\mathrm{A}(1)$ & $\mathrm{A}(2)$ & $\mathrm{B}(1)$ & $B(2)$ & $\mathrm{C}(1)$ & $\mathrm{C}(2)$ & $\mathrm{D}(1)$ & (D2) \\
\hline Latitude $(\mathrm{N})$ & $55^{\circ} 04^{\prime} 43^{\prime}$ & $55^{\circ} 04^{\prime} 46^{\prime \prime}$ & $55^{\circ} 06 ' 59^{\prime \prime} 5$ & $55^{\circ} 07 ' 01 "$ & $55^{\circ} 07^{\prime} 43^{\prime \prime}$ & $55^{\circ} 07 ' 55^{\prime \prime}$ & $55^{\circ} 10^{\prime} 34^{\prime \prime}$ & $55^{\circ} 10^{\prime} 11 "$ \\
\hline Longitude (E) & $24^{\circ} 23^{\prime} 42^{\prime}$ & $24^{\circ} 23^{\prime} 24^{\prime \prime}$ & $24^{\circ} 24^{\prime} 21^{\prime \prime} 2$ & $24^{\circ} 2430^{\prime \prime}$ & $24^{\circ} 28^{\prime} 50^{\prime \prime}$ & $24^{\circ} 28^{\prime} 51^{\prime \prime}$ & $24^{\circ} 368^{\prime \prime}$ & $24^{\circ} 362^{\prime \prime}$ \\
\hline \multirow[t]{2}{*}{ Distance class } & 3 & 3 & 5 & 5 & 10 & 10 & 20 & 20 \\
\hline & \multicolumn{8}{|c|}{ tree first layer } \\
\hline P. sylvestris & 5 & 5 & 4 & 4 & 4 & 5 & 4 & 4 \\
\hline P. abies & + & + & 2 & 2 & 1 & + & 2 & 1 \\
\hline \multirow[t]{2}{*}{ B. pendula } & - & - & + & + & - & + & - & + \\
\hline & \multicolumn{8}{|c|}{ tree second layer } \\
\hline B. pendula & + & + & + & - & + & + & + & + \\
\hline P. abies & 3 & + & 3 & 4 & 2 & 2 & 3 & 3 \\
\hline \multirow[t]{2}{*}{ Q. robur } & + & + & + & + & + & + & + & + \\
\hline & \multicolumn{8}{|c|}{ shrub layer } \\
\hline S. aucuparia & + & + & + & + & + & + & + & + \\
\hline F. alnus Mill. & + & + & + & + & + & + & + & + \\
\hline B. pendula & - & - & - & - & - & + & - & - \\
\hline C. avelana & - & + & - & + & - & - & - & - \\
\hline P. abies & + & + & + & - & + & + & + & + \\
\hline A. platanoides & + & + & + & + & - & - & - & - \\
\hline Q. robur & + & + & + & + & + & + & + & + \\
\hline Stand age & $70-80$ & $65-70$ & $90-100$ & $90-100$ & $75-80$ & $80-90$ & $80-95$ & $70-80$ \\
\hline \multirow[t]{2}{*}{ Leaf area index } & 2.63 & 2.07 & 2.5 & 2.59 & 2.61 & 2.02 & 2.47 & 2.05 \\
\hline & \multicolumn{8}{|c|}{ Litter samples composition (average g, \%) } \\
\hline Moss & 2.56 & 2.44 & 5.01 & 2.71 & 12.03 & 15.25 & 11.02 & 10.01 \\
\hline Fraction $>5 \mathrm{~mm}$ & 28.54 & 26.8 & 13.89 & 18.52 & 16.86 & 16.73 & 22.92 & 20.3 \\
\hline Fraction $<5 \mathrm{~mm}$ & 68.9 & 70.76 & 81.09 & 78.77 & 71.11 & 67.98 & 66.06 & 69.69 \\
\hline
\end{tabular}

Table 2. Soil chemical content and soil and air contamination by sulphur and nitrogen compounds in studied stands

\begin{tabular}{|c|c|c|c|c|c|c|c|c|}
\hline \multirow{2}{*}{$\begin{array}{l}\text { Plot } \\
\text { Replicates }\end{array}$} & \multicolumn{2}{|c|}{ A } & \multicolumn{2}{|c|}{ B } & \multicolumn{2}{|c|}{$\mathrm{C}$} & \multicolumn{2}{|c|}{$\mathrm{D}$} \\
\hline & $\mathrm{A}(1)$ & $\mathrm{A}(2)$ & $\mathrm{B}(1)$ & $\mathrm{B}(2)$ & $\mathrm{C}(1)$ & $\mathrm{C}(2)$ & $\mathrm{D}(1)$ & (D2) \\
\hline \multicolumn{9}{|c|}{ Soil chemical composition $(0-5 \mathrm{~cm}$ depth) } \\
\hline Nitrogen $\mathrm{g} \mathrm{kg}^{-1}$ & 0.075 & 0.099 & 0.131 & 0.116 & 0.120 & 0.132 & 0.079 & 0.075 \\
\hline Sulphur, $\mu \mathrm{g} \mathrm{m}^{-3}$ & 2.3 & 2.2 & 2.8 & 2.8 & 2.2 & 2.2 & 1.9 & 1.4 \\
\hline $\mathrm{pH}_{\mathrm{KCl}}$ & 3.5 & 3.5 & 3.9 & 3.5 & 3.5 & 3.8 & 3.4 & 3.3 \\
\hline Carbon $\mathrm{g} \mathrm{kg}^{-1}$ & 256 & 240 & 380 & 386 & 281 & 285 & 300 & 298 \\
\hline $\mathrm{P}_{2} \mathrm{O}_{5} \mu \mathrm{g} \mathrm{kg}^{-1}$ & 121 & 125 & 103 & 159 & 121 & 80 & 55 & 34 \\
\hline $\mathrm{K}_{2} \mathrm{O} \mu \mathrm{g} \mathrm{kg}^{-1}$ & 40 & 30 & 37 & 36 & 40 & 36 & 38 & 32 \\
\hline \multicolumn{9}{|c|}{ Air pollutants (Average of previous 5 years $(2007-2012)$} \\
\hline $\mathrm{SO}_{\mu \mathrm{g} \mathrm{m}}{ }^{-3}$ & \multicolumn{2}{|c|}{$2.2 \pm 0.8$} & \multicolumn{2}{|c|}{$2.8 \pm 0.8$} & \multicolumn{2}{|c|}{$2.2 \pm 0.3$} & \multicolumn{2}{|c|}{$1.4 \pm 0.2$} \\
\hline $\mathrm{NO} \mu \mathrm{g} \mathrm{m}^{-3}$ & \multicolumn{2}{|c|}{$33.9 \pm 2.4$} & \multicolumn{2}{|c|}{$12.6 \pm 1.3$} & \multicolumn{2}{|c|}{$8.4 \pm 0.2$} & \multicolumn{2}{|c|}{$8.2 \pm 1.0$} \\
\hline $\mathrm{NH} \mu \mathrm{g} \mathrm{m}^{-3}$ & \multicolumn{2}{|c|}{$276.9 \pm 51.3$} & \multicolumn{2}{|c|}{$33.1 \pm 14.1$} & \multicolumn{2}{|c|}{$2.1 \pm 0.3$} & \multicolumn{2}{|c|}{$3.2 \pm 1.2$} \\
\hline
\end{tabular}

\subsection{Sampling}

Five litter samples were taken from randomly chosen $1000 \mathrm{~m}^{2}$ area locations in each research plot (which generated 5 × $8=40$ litter samples). The samples were collected on 10 October 2013 and during April 2014. Each litter sample was compiled of 5 small randomly taken samples, each of which comprised moss, litter and humus layers sampled at a depth of $5 \mathrm{~cm}$ of the layer from the surface of $0.04 \mathrm{~m}^{2}$. The average weight $(\mathrm{g})$ of samples dried to air humidity varied between stands: A (1) - $753 \mathrm{~g}, \mathrm{~A}(2)-778 \mathrm{~g}, \mathrm{~B}(1)-1091$ g, B (2) - 1075 g, C (1) - 740 g, C (2) - 857g, D (1) - 752 g, D (2) $-990 \mathrm{~g}$. These data were used for the calculation of litter composition (average g, \%), which is given in Table 1.
The litter samples were dried to air humidity prior to analysis of content fractions. Litter fractions were separated manually using a sieve with a mesh size of $5 \mathrm{~mm}$. The moss fraction was separated manually. The data on soil chemical composition and on air pollutants in the investigated area are also given in Table 2 and are taken from Armolaitis et al. (2013) and Plaušinyte (2014). Beetles were extracted from the samples manually using sieves with holes of 5, 3 and $1 \mathrm{~mm}$ and collected using an aspirator. Adults were identified to species, larvae to family or some of them to genus levels using various specialized keys for identification of Coleoptera (Böving and Craighead 1931, Lohse 1964, Freude et al. 1967, 1974, 1983, Müller-Motzfeld, 2004). Diluted technical ethylene glycol is recommended for research work (e.g., Braun et al. 2012), but 


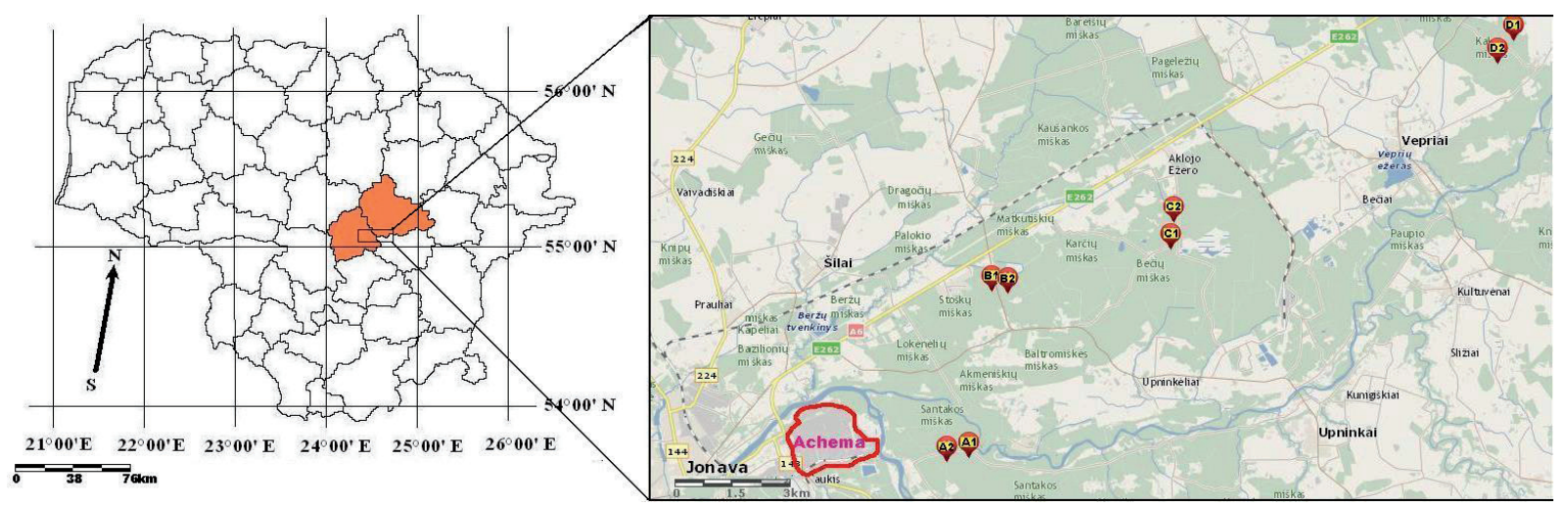

Figure 1. Maps showing locations of study sites.

because we were only preserving collected beetles we used ethanol.

\subsection{Beetle life traits for analysis}

The identified beetle species were divided by life traits and grouped according to their diet preference (diet group) and habitat preference (habitat group). The diet group consisted of zoophagous (feeding on food of animal origin), dendrophagous (feeding on tissues of trees and shrubs), herbiphagous (feeding on tissues of grasses), mycophagous (feeding on fungi), saprophagous (feeding on decayng organic matter), and mixophagous (feeding on food from both animal and plant origin) beetles. The habitat group consisted of: forest specialists (inhabiting only forests), habitat generalists (which inhabiting various habitats) and open area specialists (inhabiting open areas). Our classifications were based on the works of Thiele (1977), Nunberg (1985), Eisenbeis and Wichard (1987), Boháč et al. (2007), Tarnawski and Buchholz (2008) and Belskaya and Kolesnikova (2011).

\subsection{Data analysis}

The pollutants emitted from nitrogen fertilizer plant were responsible for changes in environmental factors in the vicinity. They could influence the environment directly (e.g., concentration of chemical compounds in air and soil) or indirectly (e.g., acidification and fertilization of soil and litter layer and exchanged vegetation structure). Therefore, we recorded parameters related to pollution, soil properties, litter layer and vegetation structure (Tables 1 and 2) and also transect parameters (distance from the plant). To reduce the number of variables to the main environmental gradient and exclude the risk of autocorrelations and synergistic or antagonistic relationships between variables, we performed principal component analysis (PCA) of environmental variables. The first axis of the PCA explained $81 \%$ of the environmental factor variation and showed the response to air pollution, mainly nitrogen content $(\mathrm{R}=-0.99)$. The second PCA axis explained $12 \%$ of variation and showed the soil properties of the forest, mainly carbon content of the litter layer $(r=0.92)$.
The third axis, which explained $6 \%$ of the total variation of environmental data, was spatially dependent and reflected the distance of the forest from the nitrogen source $(r=0.77)$. The fourth gradient dimension (axis 4) explained 1\% of the total variation and reflected the vegetation structure of the soil surface (moss layer $r=0.81$ ). The number of species, beetle abundance and life traits were dependent values, whereas four principal components were considered factors reflecting environmental variables. We performed a generalized linear model (with a log link function) to assess the influence of four environmental factors on the number of species, beetle abundance and life traits. The most suitable model was inferred using Akaike's information criteria (AIC), based on model fit (Johnson and Omland 2004). The analyses were performed using the software CanoDraw for Windows Version 4.52 (Ter Braak and Šmilauer 2003).

The IndVal (Indicator Value) procedure (Dufrêne and Legendre 1997) was applied for detecting characteristic species for different study plots. IndVal attains the maximum value (1.00) when all individuals of the species are found in a single plot (high specificity), and minimum value when the same species occur in all plots (high fidelity). Elek et al. (2001) suggested that "in many respects the IndVal approach is a quantitative characterisation of the idea of indicator species of the classical plant sociology, based on computerised randomisation procedure (...), it would be better to name the so-called indicator species as quantitative character species". These values were analyzed using $\mathrm{R}$ statistic (R Core Team 2014) and Monte-Carlo method.

Indirect ordination of the beetle assemblages inhabiting different stands at different distances from the nitrogen pollution source was performed using non-metric multidimensional scaling, calculated in WinKyst 1.0 (Šmilauer 2002) on a Bray-Curtis similarity matrix, which was visualized in an ordination diagram in the Canoco 4.5 package (Lepš and Šmilauer 2003).

To detect the relationships between beetles and selected environmental indices, redundancy analysis (RDA) was performed after testing the length of the gradient using detrended canonical correspondence analysis (DCCA). A short length of the gradient was indicative for performing the redun- 
Table 3. Influence of distance from nitrogen fertilizer plant (Distance), soil carbon content (Carbon), nitrogen contamination of the air (Nitrogen) and proportion of moss in the forest floor (Moss) on abundance, species richness and life traits of beetle assemblages, general linear model (GLM) regression statistics and Akaike's information criteria (AIC).

\begin{tabular}{lllll} 
Life traits & $\mathrm{F}$ & $\mathrm{p}$ & $\mathrm{AIC}$ & Ralation to \\
\hline Abundance & 16.130 & $<0.001$ & 42.500 & Distance \\
Species number & 25.910 & $<0.001$ & 50.742 & Distance \\
Forest species & 5.100 & 0.030 & 134.672 & Distance \\
Generalist species & 8.110 & 0.007 & 399.373 & Distance \\
Open area species & 15.860 & $<0.001$ & 95.419 & Carbon \\
Zoophagous species & 5.640 & 0.023 & 288.484 & Nitrogen \\
Dendrophagous species & 36.300 & $<0.001$ & 196.160 & Distance \\
Herbiphagous species & 15.080 & $<0.001$ & 206.389 & Carbon \\
Mycophagous sspecies & 6.060 & 0.018 & 148.744 & Nitrogen \\
Mixophagous species & 5.660 & 0.022 & 240.292 & Moss \\
Saprophagous species & 5.690 & 0.022 & 189.174 & Carbon \\
\hline
\end{tabular}

dancy analysis (RDA) (without data transformation, sample weights, or centering by species) in CANOCO 4.5 software (Ter Braak and Šmilauer 2003). The Monte Carlo permutation test was used to evaluate the significance of the first ordination axis and that of all canonical axes together. The following were considered environmental data: presence of pine (Pinus sylvestris) and spruce (Picea abies) in the stands, leaf area index (LAI), moss fraction (Moss), fraction of twigs, cones and leaves $(\mathrm{Fra}>5)$, fraction of needles and humified organic residues $(\mathrm{Fra}<5)$, soil content of nitrogen $(\mathrm{N})$, sulphur (S), carbon (C), phosphorus (P) and potassium (K), and air content of sulphur oxide (SO), nitrogen oxides (NO) and ammonium $(\mathrm{NH})$.

\section{Results}

\subsection{Assemblages}

During the study, 1,340 adults and 132 beetle larvae were caught (Electronic Appendix). The mean abundances, species number, and proportions of forest species and dendrophagous species increased with increasing distance from the pollution source, while the proportion of generalist species decreased (Table 3, Fig. 2). Other life traits were not dependent on the distance from the nitrogen fertilizer plant. With carbon content in the litter layer increasing the percentages of open area species, herbiphagous species and saprophagous species in assemblages increased (Table 3, Fig. 2). The proportions of zoophagous and mycophagous species declined with increasing nitrogen contamination of the air, and the proportion of mixophagous species increased with increasing proportion of moss in the forest floor (Table 3, Fig. 2).
A non-metric multidimensional scaling (NMDS) performed using a Bray-Curtis similarity matrix of the beetle assemblages indicated that those had a close association with the first two dimensions (final stress $=0.24$ ) (Fig. 3). The first axis seemed to separate assemblages inhabiting stands at different distances from the pollution source from the left to the right side of the ordination plot.

The first two RDA axes explained $41.9 \%$ of the species data and $30.9 \%$ of the species-environment data (Fig. 4). The RDA grouped the beetle assemblages in the order of stand distance from the plant - from the nearest (left upper side of the diagram) to the farthest (left lower side). The first axis was associated with the distance of the studied stands from the pollution source $(+0.72)$ and soil chemistry: sulphur $(-0.83)$, potassium (-0.79) and soil $\mathrm{pH}(-0.62)$. The second RDA axis was correlated with the fraction of humified organic residues $<5 \mathrm{~mm}(+0.77)$ and moss fraction. The moss fraction and the proportion of spruce in the stand were positively correlated with increasing distance from the plant. The LAI index, fraction of twigs, cones, leaves (Fra $>5$ ) and fraction of needles, humified mortmass $(\mathrm{Fra}<5)$ were positively correlated with decreasing distance from the plant. Also, concentration of sulphur and phosphorus in the soil was higher in stands located closer to the plant.

\subsection{Species}

The IndVal analysis identified only one species - Atheta fungi (common generalist species), which preferred stands located close to the nitrogen pollution source (Table 4). Two species, Brassicogethes aeneus and Micrambe abietis were characteristic of the stands situated more than $5 \mathrm{~km}$ away from the pollution source. A further two species, Bryaxis 

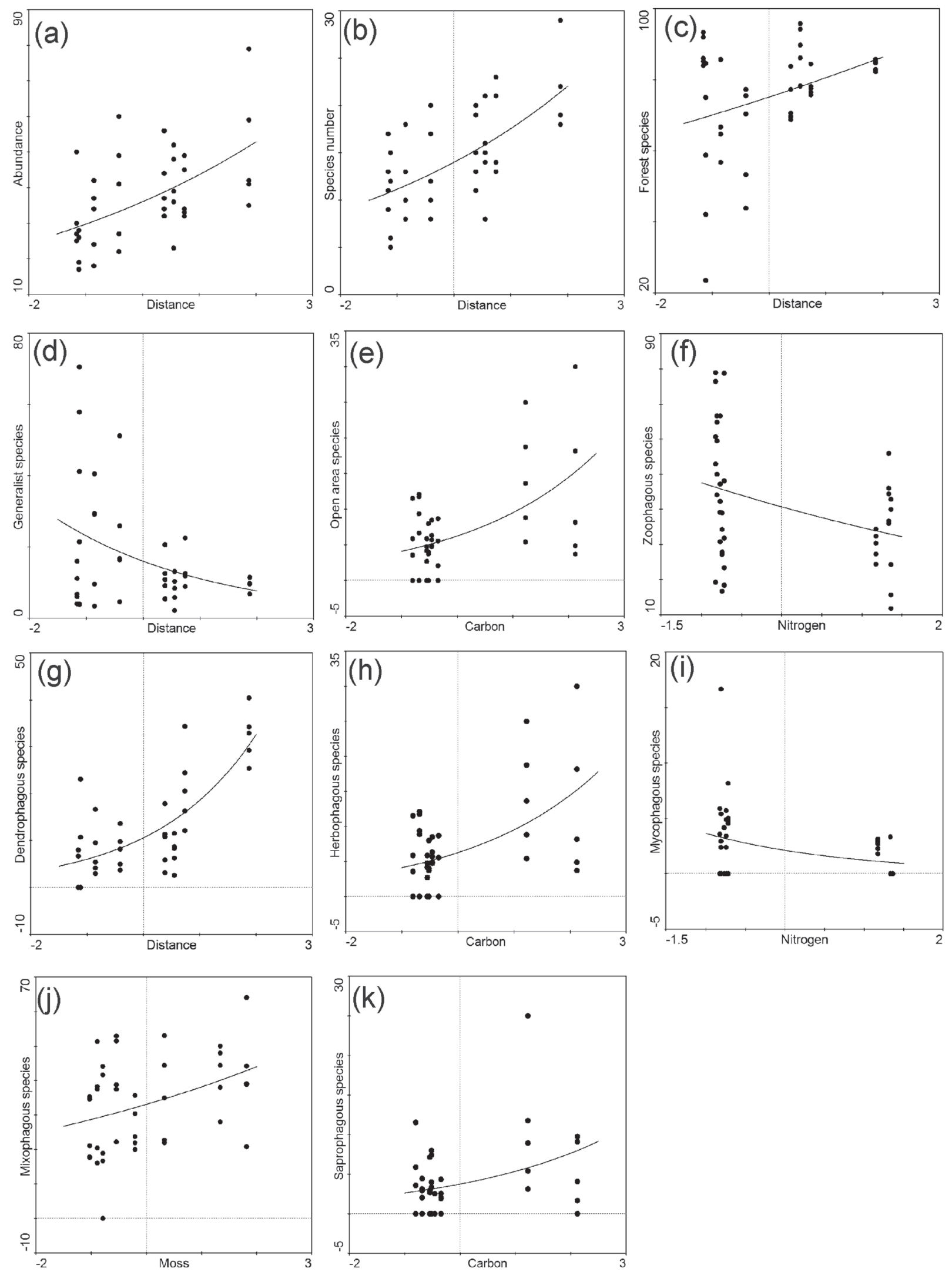

Figure 2. Relationship between species number (a), abundance of beetles (b), proportion of forest species (c), generalist species (d), open area species (e), zoophagous species (f), dendrophagous species (g), herbiphagous species (h), mycophagous species (i), mixophagous species ( $\mathrm{j}$ ) and saprophagous species $(\mathrm{k})$ and the distance from the nitrogen fertilizer plant (a, b, c, d, g), soil carbon content (e, h, $k)$, nitrogen contamination of the air (f, i) and proportion of moss in the litter (j). 
Figure 3. Non-metric multidimensional scaling analysis (NMDS) ordination of beetle assemblages in stands at different distances from the nitrogen fertilizer plant $($ NMDS stress $=0.24)$; $3-3 \mathrm{~km}, 5-5 \mathrm{~km}, 10-10 \mathrm{~km}$ and $20-20 \mathrm{~km}$; a and $\mathrm{b}$ - indicate plot replication.

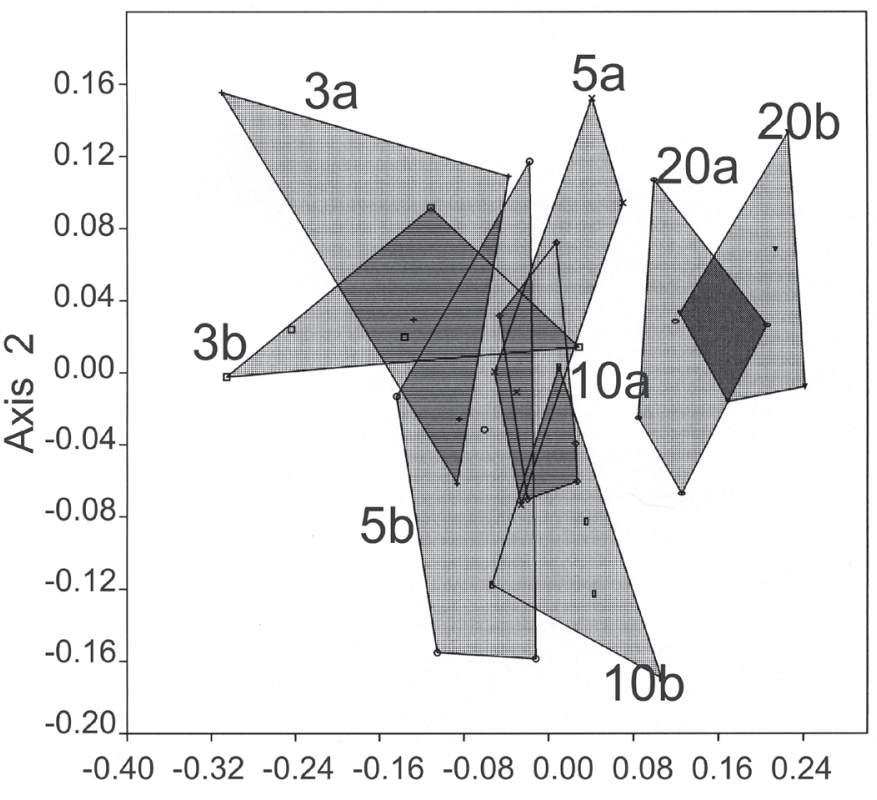

Axis 1
Figure 4. RDA of stands and beetle assemblages at different distances from the nitrogen fertilizer plant (3, 5,10 and 20) replicated twice (a and b); environmental factors: participation of pine (Pinus), spruce (Picea) in the stands, leaf area index (LAI), moss fraction (Moss), fraction of twigs, cones, leaves (Fra $>5$ ), fraction of needles, humified mortmass $($ Fra $<5)$, soil content of nitrogen $(\mathrm{N})$, sulphur (S), carbon $(\mathrm{C})$, phosphorus $(\mathrm{P})$ and potassium $(\mathrm{K})$ and air content of sulphur oxide (SO), nitrogen oxides (NO) and ammonium $(\mathrm{NH})$, acronyms of the names of the species in the Appendix.

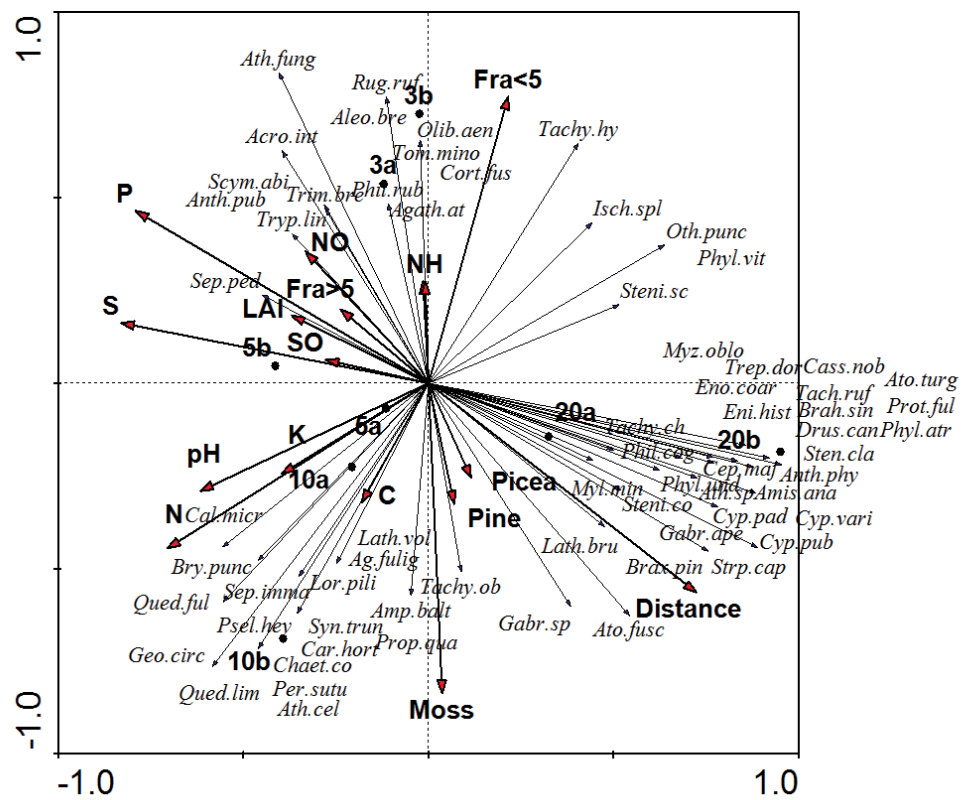

crease of emission of pollutants. The moss layer is important for many species of coleoptera, such as the forest dwellers Carabus hortensis and Carabus glabratus (Skłodowski and Garbalińska, 2011), which suggests that a higher content of moss in the forest floor can stimulate an increasing proportion of forest species in the beetle assemblages. We found only mixophagous species in beetle assemblages increasing in numbers in association with increasing richness of the moss layer.

The RDA analysis also showed a clear evidence of decrease of proportions of both fine and coarse fractions of the litter layer and an increasing proportion of moss in stands located further from the nitrogen fertilizer plant (Fig. 4). A rich moss layer can have a negative effect on the number of carabid beetles (Guillemain et al., 1997), but it can positively af- 
Table 4. The IndVal (Indicator Value) and its statistics for species, which are specific for stands at different distances from the pollution source.

\begin{tabular}{lllll} 
Species & Distance class & IndVal & p-value & frequency \\
\hline Atheta fungi & 3 & 0.507 & 0.007 & 31 \\
Brassicogethes aeneus & 5 & 0.722 & 0.001 & 24 \\
Micrambe abietis & 5 & 0.511 & 0.003 & 14 \\
Bryaxis puncticollis & 10 & 0.466 & 0.017 & 33 \\
Quedius limbatus & 10 & 0.429 & 0.009 & 6 \\
Cyphon pubescens & 20 & 0.723 & 0.001 & 11 \\
Strophosoma capitatus & 20 & 0.632 & 0.002 & 20 \\
Cephenium majus & 20 & 0.600 & 0.001 & 6 \\
Anthonomus phyllocola & 20 & 0.532 & 0.003 & 34 \\
Cyphon padi & 20 & 0.500 & 0.001 & 12 \\
Phyllotreta undulata & 20 & 0.467 & 0.002 & 10 \\
Brachonyx pineti & 20 & 0.457 & 0.005 & 14 \\
Gabrius appendiculatus & 20 & 0.450 & 0.005 & 6 \\
Cyphon variabilis & 20 & 0.389 & 0.014 & 7 \\
Philonthus cognatus & 20 & 0.300 & 0.045 & 3 \\
\hline
\end{tabular}

fect the number of forest species (Koivula et al. 1999, Magura et al. 2001). We observed increase in abundance, number of beetle species, proportions of forest and dendrophagous species in beetle assemblages with increasing distance from the plant, which can be partly associated with decreasing proportion of the coarse litter fraction and increasing proportion of moss in the samples. This can probably also be related to higher sulphur and phospohorus concentrations in the soil in the stands situated closer to the plant, which can inhibit many populations of beetles, especially those sensitive to contamination. Similar findings about beetles and contamination have been reported by Skalski et al. (2010). The findings of higher numbers of species and individuals and the presence of forest and dendrophagous species in the stands farthest from the chemical plants seem to support the supposition that a less polluted forest habitat is more beneficial for species richness and number of individuals of forest dwellers, especially for species which feed on trees. A similar observation in the case of spiders and carabid beetles inhabiting polluted environments was described by Horvath et al (2001) and Kędzior et al. (2014). Magura et al. (2013) also found higher richness of mycetophilous staphylinid species in less disturbed areas. The presented and cited results suggest that the dispersion of contaminants from the nitrogen plant depends on the prevailing wind direction. The influence of wind direction on element concentration in soils has been highlighted by Simon et al. (2012).
We also found that a high content of organic carbon in the upper horizon of the soil had a positive effect on the numbers of open area phytophagous and saprophagous species in beetle assemblages.

The nitrogen content in the soil affects some life traits of arthropods (Hadad et al. 2000, Perner et al. 2003). An increasing proportion of zoophagous species in beetle assemblages in the forests fertilized by amonium nitrate ( $28 \%$ of nitrogen) and carbamide ( $46 \%$ of nitrogen) has been detected during controlled experiment (Skłodowski 1995). Therefore, we suggest considering that air and soil contamination by the nitrogen pollutants could positively affect zoophagous beetles in our studied stands. Unfortunately, published information on relationships between contamination by nitrogen pollutants and litter dwelling beetles is very scarce. Also, there is little of published information on the reactions of herbivorous insects to nitrogen pollution. For instance, the abundance of larvae of sawfly can be positively associated with plant nitrogen content under a low pollution level and negatively associated with plant nitrogen content under high pollution (Jones et al. 2011). Despite our findings on some possible interactions between air pollution with nitrogen pollutants and litter dwelling zoophagous beetles, the details of this relationship remain unclear and require a deeper study.

Some interactions between nitrogen contamination and soil fungi, which could be potential food for mycophagous beetles, have been described in previous papers. For example, Brandrud and Timmermann (1998) established the 
decline of the biomass of fungi caused by nitrogen input to the soil. Michael and Marx (1996) reviewed many papers on interactions between nitrogen pollution and mycorrhizal fungi and considered that though nitrogen deposition did not cause direct damage to the mycorrhizae, it could be a reason for the slowdown of processes of mycorrhizae and for higher sensitivity of fungi to infection by antagonists or development inhibitors. So, we propose that higher concentrations of nitrogen pollutants in the air close to the plant can reduce the amount of fungi and consequently reduce the abundance of mycophagous beetles.

\subsection{Species}

The IndVal analysis detected only three species: Atheta fungi, Micrambe abietis and Brassicogethes aeneus associated with stands situated at the distances of three and five $\mathrm{km}$ from the nitrogen fertilizer plant. Probably, reduction of the moss layer and the presence of a high content of organic carbon in the soil could stimulate such a guild of indicator species in these stands. Avoidance of mossy litter by A. fungi was found in our previous studies (Tamutis and Skłodowski 2015). The other two species seem to react to the presence of nitrophilic plants (e.g., Acer platanoides, Corylus avelana, Quercus robur, Picea abies) in the stands. The trophic strategy of M. abietis is connected with spruce, but quite often it is regarded as a saproxylic species (Goßner et al. 2006). The abundant presence of this species in stands situated $5 \mathrm{~km}$ away from the nitrogen fertilizer plant seems to be stimulated by the presence of spruce, which was abundant in this stand due to over-fertilization with plant-emitted nitrogen during the period 1972-1990. A third species, B. aeneus is a typical phytophagous species, the main pest of rape in agriculture fields. Its abundant presence in the litter of coniferous forests is not widely known, though for the litter of broadleaved forests or forested grasslands for overwintering by this species was detected by Marsczali and Nádasy (2006). A lot of deciduous trees, such as Acer platanoides, Corylus avellana, Quercus robur, were represented in the shrub layer in the studied stands (Table 1), and they resulted in an abundant leaf fall in autumn. A higher content of leaves in the litter probably increased its attractiveness for $B$. aeneus for overwintering, and probably $B$. aeneus could tolerate contamination of the litter layer by nitrogen pollutants. It seems that all these three beetle species can be considered indirect indicators of ecosystems affected by nitrogen pollutants.

The IndVal analysis showed the next twelve species associated with farthest stands situated 10 and $20 \mathrm{~km}$ away from the plant. Nine of them (Bryaxis puncticollis, Quedius limbatus, Cyphon pubescens, Strophosoma capitatus, Cephenium majus, Anthonomus phyllocola, Cyphon padi, Brachonyx pineti and Cyphon variabilis) belong to the group of forest species, two species (Philonthus cognatus and Gabrius appendiculatus) are generalists; and Phyllotreta undulata is an open habitat species. According to the feeding strategy, the life traits of these twelve species are more diverse: zoophagous (5 species), dendrophagous (3 species), herbiphagous (1 species) and mixophagous (3 species). Predator species
B. puncticollis, C. majus, Q.limbatus, G. appendiculatus and $P$. cognatus prey on litter microarthropods, especially Collembola (Shomann et al. 2008), armored mites and small larvae of Diptera (Belskaya and Kolesnikova 2011), the abundance of which is strongly affected by nitrogen deposition (Xu et al. 2009). The presence of the above-mentioned five species in groups of beetles associated with forests at a distanced 10 and $20 \mathrm{~km}$ from nitrogen fertilizer plant suggests its good microhabitats and food supply there.

The species classified as dendrophagous, A. phyllocola and $B$. pineti, were strictly related to pines and were associated with assemblages inhabiting forests at a distance of $20 \mathrm{~km}$ from the nitrogen fertilizer plant. The third dendrophagous species, $S$. capitatum, is regarded as a polyphagous species (Lindelöw and Björkman 2001). The records of these beetles as species associated with a less polluted forest environment can demonstrate their choice of forest litter for overwintering in the studied stands and probably a higher suitability of pine needles for the food of these needle eaters. However, which factor was essential for the distribution of this species in the studied stands remains undetermined. Presumably, it could be the attractiveness of food. Nitrogen pollution of the air can be responsible for changes in needle chemistry (GrodzińskaJurczak 1998). Such changes can have a negative effect on the quality of food and reduce the quantity of populations of these dendrophagous species in the stands situated closer to the nitrogen fertilizer plant.

The IndVal analysis showed three mixophagous species (Cyphon padi, C. variabilis and C. pubescens) as associated with the studied stands at the farthest distance from the nitrogen fertilizer plant. These species prefer forest habitats (Dapkus and Tamutis 2008), and they probably found beneficial conditions in the "cleanest" forest stand of our studied sites. Their presence in the group of associated species of stands farthest from the plant could be related with their preference to forest habitats, but why were they so abundant? Most likely, that was related to the moss-rich litter in the studied stands. Previous findings on the biology of some Cyphon species (Klausnitzer and Pospisil 1991) suggest that the larvae of these three species could survive in the moss, which provides high levels of moisture, and consequently the abundant presence of overwintering adults of these species in the litter is not accidental.

In the case of species groups that showed preference to the stands farthest from the nitrogen fertilizer plant, additional attention could be paid to Cephennium majus. The preference of this species to moss-rich layer of mature pine stands has been observed in previous studies as well (Tamutis and Skłodowski 2015). So, we suggest this species to be an indicator of unpolluted ecosystems of pine forest, which are commonly characterized by a well developed and rich moss layer (Proctor 2000).

A wide range of choices of overwintering shelters for a phytophagous open area species $P$. undulata is known (Hiiesaar et al., 2009); however, its overwintering in coniferous forests has not been documented before. During spring and summer, P. undulata feed on Brassicaceae plants, and it 
is widely considered the main pest of rape in agriculture. The reasons of the presence of this species in the studied stand could be accidental and we do not rate $P$. undulata as an indicators species for a less polluted pine forest environment. The study confirmed the need to combine observations made at different levels of the food chain to explain the differences in invertebrate species composition. This is a hot topic in contemporary scientific literature (e.g., Simon et al. 2016).

Ackowledgements: We are grateful to Professors V. Marozas and A. Augustaitis (Aleksandras Stulginskis University) for discussion, assistance and useful comments on this study. Many thanks to Dr. S. Venn (University of Helsinki) and V. Zaliene (Vilnius University) for valuable comments and English improvements of the manuscript. The study was carried out within the framework of the national project No VP13.1-ŠMM-08-K-01-025 entitled "Specific, genetic diversity and sustainable development of Scots pine forest to mitigate the negative effects of increased human pressure and climate change" supported by the EU Social Fund.

\section{References}

Aber, J., K. Nadelhoffer, P. Steudler and J.M. Melillo. 1989. Nitrogen saturation in northern forest ecosystems - hypotheses and implications. BioScience 39: 378-386.

Anonymous. 2015. About AB “Achema", Available at: http://www. achema.lt. Accessed 25 November, 2015.

Armolaitis, K., E. Bartkevičius, R. Juknys, A. Raguotis and J. Šepetienè. 1999. The influence of pollutants of Joint Stock Company "Achema" to the forest ecosystems [AB „Achemos“ teršalu poveikis miško ekosistemoms]. In: R. Ozolinčius (ed.) The State of Lithuanian Forests and their Affected Factors [Lietuvos mišku būkle ir ja salygojantys veiksniai]. Lututè, Kaunas, pp. 44-65.

Armolaitis, K. and V. Stakènas. 2001. The recovery of damaged pine forests in an area formerly polluted by nitrogen. Scientific World 1: 384-393.

Armolaitis, K., V. Stakènas, E. Plaušinytė, J. Aleinikovienė, I. Varnagirytė-Kabašinskienė, V. Marozas, E. Bartkevičius, A. Augustaitis and J. Šepetinè. 2013. Recovery of damaged by pollution Scots pine (Pinus sylvestris L.) ecosystems near SC „Achema“. [AB „Achema“ teršalų pažeistų pušynų ekosistemų atsistatymas]. Miškininkystè 73: 31-44.

Augustaitis, A. 2005. Assesment of the integrated impact of natural and anthropogenic environmental factors on mean defoliation of Scots pine stands and its prognosis [Natūralių ir antropogeninių aplinkos veiksnių kompleksiškos įtakos pušynų vidutinei defoliacijai vertinimas ir prognozè]. Miškininkystè (58): 51-62.

Augustaitis, A., I. Augustaitienè, A. Kliučius, E. Bartkevičius, G. Mozgeris, D. Šopauskienė, I. Eitmanavičiūtė, K. Arbačiauskas, R. Mažeikytė and I. Baužienè. 2005. Forest biota under changing concentration in acidifying compounds in the air and their deposition. Baltic For. 11(2): 84-93.

Belskaya, A.E. and A. Kolesnikova. 2011. Species composition and ecological ccharacteristics of rove beetles (Coleoptera, Staphylionidae) in the southern taiga of the Middle Urals. Entomological Review 91: 599-610.

Boháč, J., Matějíček, J. and R. Rous. 2007. Check-list of staphylinid beetles (Coleoptera, Staphylinidae) of Czech Republic and the division of species according to their ecological characteristics and sensitivity of human influence. Časopis Slezského Zemského Muzea, Série A - Vědy Přirodní 56: 227-276.
Boyer, E.W., Goodale, C.L, Jaworski, N.A. and Howarth, R.W. 2002. Anthropogenic nitrogen sources and relationships to riverine nitrogen export in the northeastern U.S.A. Biogeochemistry 57: 137-169.

Brandrud, T.E. and V. Timmermann. 1998. Ectomycorrhizal fungi in the NITREX site at Gårdsjön, Sweden; below and above-ground responses to experimentally-changed nitrogen inputs 19901995. For. Ecol. Manage. 101: 207-214.

Böving, A.G. and F.C. Craighead. 1931. An illustrated synopsis of the principal larval forms of the order Coleoptera. Brooklyn Entomol. Soc., Brooklyn.

Braun, M., E. Simon, I. Fábián and B. Tóthmérész. 2012. Elemental analysis of pitfall-trapped insect samples: effects of ethylene glycol grades. Entomol. Exp. Appl. 143: 89-94.

Chappelka, A.H., and P.H. Freer-Smith. 1995. Predisposition of trees by air pollutants to low temperatures and moisture stress. Environ. Pollut. 87:105-107.

Dapkus, D. and V. Tamutis. 2008. Assemblages of beetles (Coleoptera) in a peatbog and surrounding pine frests. Balt. J. Coleopterol. 8: 31-40.

Dufrêne, M. and P. Legendre 1997. Species assemblages and indicator species: the need for a flexible asymmetrical approach. Ecol. Monogr. 67: 345-366.

Eisenbeis, G. and W. Wichard 1987. Atlas of the Biology of Soil Arthropods. Springer Verlag, Berlin.

Elek, Z., Magura, T. and B. Tóthmérész. 2001. Impacts of non-native Norway spruce plantation on abundance and species richness of ground beetles (Coleoptera: Carabidae). Web Ecol. 2: 32-37.

Emberson, L.D., P. Büker and M.R. Ashmore. 2007. Assessing the risk caused by ground level ozone to Europe forest trees: A case study in pine, beech, and oak across different climate regions. Environ. Pollut. 147: 454-466.

Felzer, B.S., T. Cronin, J.M. Reilly, J.M. Melillo and X. Wang. 2007. Impacts of ozone on trees and crops. C. R. Geosci. 339: 784-798.

Freude, H., K.W. Harde and G.A. Lohse. 1967. Die Käfer Mitteleuropas. Band 7. Clavicornia. Goecke and Evers, Krefeld.

Freude, H., K.W. Harde and G.A. Lohse. 1974. Die Käfer Mitteleuropas. Band 5. Staphylinidae II (Hypocyphtinae und Aleocharinae, Pselaphinae. Goecke and Evers, Krefeld.

Freude, H., K.W. Harde and G.A. Lohse. 1983. Die Käfer Mitteleuropas. Band 11.Familienreihe: Rhynchophora. Goecke and Evers, Krefeld.

Führer, E. 1985. Air pollution and the incidence of forest insect problems. J. Appl. Entomol. 99: 371-377.

Galloway, J.N., H. Schlesinger, H. Levy, A. Michaels and J.L. Schnoor. 1995. Nitrogen fixation: atmospheric enhandementenvironmental response. Global Biogeochem. Cycles 9: 235-252.

Goßner, M., Engel, K. and U. Ammer. 2006. Effects of selection felling and gap felling of forest arthropod communities: a case study in spruce-beech stand of souther Bavaria. Eur. J. Forest Res. 125: 345-360.

Grodzińska-Jurczak, M. 1998. Conifer epicuticular wax as a biomarker of air pollution: an overview. Acta Soc. Bot. Pol. 67: 291-300.

Guillemain, M., M. Loreau and T. Daufrense. 1997. Relationship between the regional distribution of carabid beetles (Coleoptera, Carabidae) and the abundance of their potential prey. Acta Oecol. 18: 465-483.

Haddad, N.M., J. Haarstad and D. Tilman. 2000. The effects of long-term nitrogen loading on grassland insect communities. Oecologia 124: 73-84. 
Heliövaara, K. and R. Väisänen. 1988. Interactions among herbivores in three polluted pine stands. Silva Fenn. 22: 283-292.

Hiiesaar, K., Williams, I., Luik, A., Metspalu, L. Muljar, R., Jõgar, K., Karise, R., Mänd, M., Svilponis, E. and A. Ploomi. 2009. Factors affecting cold hardiness in the small stripped flea beetle, Phyllotreta undulata. Entomol. Exp. Appl. 131: 278-285.

Horváth R., T. Magura and S. Csaba. 2001. Effects of immission load on spiders living on black pine. Biodivers. Conserv. 10: 1531-1542.

Johnson, J.B. and K.S. Omland 2004. Model selection in ecology and evolution. Trends Ecol. Evol. 19: 101-108.

Jones, M.E., M.E.Fenn and T.D. Paine. 2011. The effect of nitrogen additions on bracken fern and its insect herbivores at sites with high and low atmospheric pollution. Arthropod-Plant Interactions 5: 163-173.

Kędzior. R., T. Skalski and P. Mundała. 2014. Diversity of carabid beetle assemblages (Coleoptera: Carabidae) in a post-industrial slag deposition area. Balt. J. Coleopterol. 14: 219-228.

Klausnitzer, B. and P. Pospisil. 1991. Larvae of Cyphon sp. (Coleoptera, Helodidae) in ground waters. Aquat. Insect 13: 161-165.

Koivula, M., P. Punttila, Z. Haila and J. Niemelä. 1999. Leaf litter and the small-scale distribution of carabid beetles (Coleoptera, Carabidae) in the boreal forest. Ecography 22: 424-435.

Kupčinskienė, E., J. Nemaniūtè, D. Dailidienė and A. Krasauskas 2000. Monitoring of needle surface characteriscs of Pinus sylvestris trees near source of industrial pollution. Baltic For. 6: $37-46$.

Lepš. J. and P. Šmilauer. 2003. Multivariate Analysis of Ecological Data Using CANOCO. Cambridge University Press, Cambridge.

Lindelöw, Å. and Ch. Björkman. 2001. Insects on lodgepole pine in Sweden - current knowledge and potential risks. For. Ecol. Manage. 141: 107-16.

Logan, J.A. 1983. Nitrogen oxides in the troposphere: Global and regional budgets. J. Geophys. Res. 88: 10785-10807.

Lohse, G.A. 1964. Familie Staphylinidae I (Micropeplinae bis Tachyporinae). In: Freude, H., Harde, K.W., Lohse, G. A. (eds.). Die Käfer Mitteleuropas. Band 4. Goecke and Evers, Krefeld.

Lukac, M. and D.L. Godbold. 2011. Soil Ecology in Northern Forests. A Belowground View of Changing World. Cambridge University Press, Cambridge.

Magura, T., V: Ködöböcz and B. Tóthmérész. 2001. Effects of habitat fragmentation on carabids in forest patches. J. Biogeogr. 28: 129-138.

Magura, T., D. Nagy and B. Tóthmérész. 2013. Rove beetles respond heterogenously to urbanization. J. Insect Conserv. 17: 715-724.

Manion, P.D. and D. Lachance. 1992. Forest decline concepts: an overview. In: P.D. Manion and D. Lachance. (eds.), Forest Decline Concepts. APS Press, St. Paul. MN. pp. 181-190.

Marozas, V., E. Kupčinskienė and A. Stiklienè. 2008. Changes of understory vegetation in middle age pine forests under impact zone of nitrogen fertilizers enteprise "Achema". Miškininkyste 64: $30-37$.

Marczali, Z. and M. Nádasy. 2006. Wintering characteristic of the Melligethes species in Hungary. Journal of Central European Agriculture 7: 283-288.

Mattson, W.J. 1980. Herbivory in relation to plant nitrogen content. Ann. Rev. Ecol. Syst. 11: 119-161.

Michael, L.C. and D.H.Marx. 1996. Atmospheric nitrogen deposition and the mycorrhizae of southern commercial forest trees.
Impact of air pollutants on southern pine forests. Ecol. Stud. 118: 337-387.

Müller-Motzfeld, G. (Ed.) 2004. Band 2. Adephaga 1. Carabidae (Laufkäfer). In: Freude, H., Harde, K.W., Lohse, G. A., Klauznitzer, B. (eds), Die Käfer Mitteleuropas. Spectrum-Verlag (Heidelberg/Berlin), 2. Auflage.

Nunberg, M. 1985. Klucze do oznaczania owadów. Polski Cz. XIX (15): Chrzaszcze - Coleoptera: Grzybinki - Leiodidae. Państwowe Wydawnictwo Naukowe, Warszawa.

Perry, D.A. 1994. Forest Ecosystems. The Johns Hopkins University Press, Baltimore.

Perner, J., Voigt, W., Bährmann, R., Heinrich, W., Marstaller, R., Fabian, B., Gregor, K., Lichter, D., Sander, F.W. and T.H. Jones. 2003. Responses of arthropods to plant diversity: changes after pollution cessation. Ecography 26: 788-800.

Plaušinyte, E. 2014. Changes in the contition of forest ecosystems exposed by technogenic emission from nitrogen fertilizer plant under reduced pollution [Azotinių trąšu gamyklos technogeninès taršos paveiktų miško ekosistemų būklès pokyčiai sumažèjus taršai] Dissertation, Aleksandras Stulginskis University.

Proctor, M.C.F. .2000. Physiological ecology. In: Shaw, A. and Goffinet, B (eds) Bryophyte Ecology. Cambridge University Press, Cambridge, pp. 225-247.

R Core Team 2014. R: A language and environment for statistical computing. R Foundation for Statistical Computing, Vienna, Austria. R version 3.1.2 (2014-10-31) "Pumpkin Helmet" URL http://www.R-project.org/.

Rizvi, C.H., T. Gauquelin, C. Gers, F. Guérold, C Pagnout and V. Baldy. 2012. Calcium-magnezium liming of acified forests catchments: effect on humus morphology and functioning. Appl. Soil Ecol. 62: 81-87.

Shomann, A., K. Afflebrach and O. Betz. 2008. Predatory behavior of some Central European pselaphine beetles (Coleoptera: Pselaphinae) with description of relevant morphological features in their heads. Eur. J. Entomol.105: 889-907.

Simon, E., S: Harangi, M. Braun, C. Cserháti, I. Fábián and B. Tóthmérész. 2016a. Elemental concentrations in deposited dust on leave along an urbanization gradient. Sci. Total Environ. 490: 514-520.

Simon, E., S. Harangi, E. Baranyai, M. Braun, I. Fábián, Sz. Mizser, L. Nagy and B. Tóthmérész. 2016b. Distribution of toxic elements between biotic and abiotic components of terrestrial ecosystem along an urbanization gradient: Soil, leaf litter and ground beetles. Ecol. Indic. 60: 258-264.

Skalski, T., D. Stone, P. Kramarz and R. Laskowski. 2010. Ground beetle community responses to heavy metal contamination. Balt. J. Coleopterol. 10: 1-12.

Skłodowski, J. 1995. Soil fertilization and acidification effect on the rate of development of epigeic carabid (Coleoptera, Carabidae) communities in a scots pine forest plantation. Folia Forest. Pol. Seria A-Forestry 37: 21-46.

Skłodowski, J. and P. Garbalińska. 2011. Ground beetle (Coleoptera, Carabidae) assemblages inhabiting Scots pine stands of Puszcza Piska Forest: six-year responses to a tornado impact. ZooKeys 100: 371-392.

Stravinskienè, V. 2004. Scots pine (Pinus sylvestris L.) radial growth in the vicinity of nitrogen fertilizers plant "Achema" in Lithuania. Ecológia 23: 438-445.

Šmilauer, P. 2002. WinKyst 1.0. Ceske Budejovice, available from: http://www.canodraw.com/winkyst.htm.

Tamutis, V. and J. Skłodowski. 2015. Zespoły chrąszczy sćiółkowych w gospodarczych i chronionych borach sosnowych - efekt 15 lat 
ochrony rezerwatowej [Coleoptera assemblages inhabiting managed and preserved pine forests - the efect of fifteen years of rezerve conservation]. Sylwan 159: 142-150.

Tarnawski, D. and L. Buchholz. 2008. Klucze do oznaczania owadów. Polski Cz. XIX (34a): Chrząszcze - Coleoptera: Sprężykowate -Elateridae. Czesść ogólna oraz podrodziny: Agrypninae, Negastriinae i Diminae. Polskie Towarzystwo Entomologiczne, Toruń.

Ter Braak, C.J.F. and P. Šmilauer. 2003. Multivariate Analysis of Ecological Data Using CANOCO. Cambridge University Press, New York.

Thiele, H.U. 1977. Carabid Beetles in their Environment: A Study on Habitat Selection by Adaptations in Physiology and Behaviour. Springer, Berlin

Thormann, M.N. 2006. Lichens as indicators of forest health in Canada. The Forestry Chronicle 82: 335-343.
Throop, H.L. and M.T. Lerdau. 2004. Effects of nitrogen deposition on insect herbivory: implication for community and ecosystem processes. Ecosystems 7: 109-133.

Xu, G.L., P. Schleppi, M.H. Li and S.L. Fu. 2009. Negative responses of Collembola in a forest soil (Alptal, Switzerland) under experimentally increased $\mathrm{N}$ deposition. Environ. Pollut. 157: 2030-2036.

Received May 27, 2016

Revised September 15, 2016 Accepted November 30, 2016

\section{Electronic supplement}

The list of species, life traits and number of individuals of beetles collected in the pine forest at different distances from the nitrogen fertilizer plant The file may be downloaded from www.akademiai.com. 